\title{
PEMINANGAN DALAM ISLAM \\ (PERSPEKTIF HADIS NABI SAW)
}

\author{
A. Darussalam \\ Program Studi Ilmu Hadis \\ Fakultas Ushuluddin Filsafat dan Politik \\ Universitas Islam Negeri Alauddin Makassar \\ email: andidarus59@gmail.com
}

\section{Abstract}

The purpose of this research is to find out and explain the meaning contained in the hadith about khitbah. This research is a library research consisting of the books of hadith, verses of the Qur'an and supporting data as well as information needed to interpret the data by referring to the explanations of the scholars in the books of hadith, tafseer and so forth. Analysis of the hadith about khitbah is divided into 3 parts: the essence of khitbah, the rules related to khitbah and wisdom (hikmah) from khitbah. This research is expected to contribute ideas or can add information and enrich the treasures of Islamic intellectuals, provide an understanding of the hadith in particular the community about khitbah so that it knows the limits before and after khitbah and this research is useful as a guide in understanding and practice (sunnah) of Rasulullah saw.

Key words: hadith, khitbah, marriage, Islam.

\section{Pendahuluan}

Salah satu prinsip kehidupan dalam sosial kemasyarakatan adalah pernikahan yang merupakan sunnatullah bagi alam semesta, semua tumbuhan dan hewan (kawin). Tujuan pernikahan menurut Islam adalah untuk memenuhi bimbingan agama untuk membangun keluarga yang sakinah, mawaddah wa rahmah, oleh karenanya pernikahan adalah dorongan bagi setiap Muslim yang mampu dan yang tidak 
ingin jatuh dalam dosa (QS. al-Nisā/4). Sebelum upacara pernikahan, seorang pria biasanya meminang atau berkhitbah kepada wanita yang akan menjadi istri. Khitbah berarti mengekspresikan permintaan untuk menikahi pria dengan wanita atau sebaliknya atau hanya melalui perantara yang tepercaya.

Jika kedua belah pihak sepakat untuk menikah, maka peminangan dapat dilakukan secara langsung atau tidak langsung (tersirat), dan dapat dipahami bahwa hukum peminangan bersifat tidak wajib (QS. al-Baqarah/2: 235). Praktik masyarakat saat ini menunjukkan bahwa peminangan adalah tahap awal yang hampir pasti akan dilakukan dari berbagai tahapan pernikahan, dengan proses sesuai dengan kebiasaan masing-masing daerah karena ada pesan moral dan etiket untuk memulai rencana membangun sebuah rumah tangga. Peminangan memiliki kandungan atau status (akibat) hukum, dalam arti masih ada batasan yang harus dijaga agar pasangan yang bertunangan tidak bisa bersama sampai upacara pernikahan. ${ }^{1}$ Sebagaimana sabda Nabi saw. "tidak ada pria dengan satu wanita kecuali ketiganya adalah setan."

Bahasan terkait khitbah/peminangan ada beberapa hadis yang membicarakannya, penulis mencoba menyelidiki lebih jauh dengan permasalahan "bagaimana khitbah dalam Islam dilihat dari perspektif hadis Nabi saw.", dengan artikel ini berharap masyarakat menambah khazanah keilmuan dalam memahami peminangan. Melalui pemahaman ini, diharapkan mampu menciptakan generasi Islami yang mempunyai budi pekerti selain kemampuan intelektual yang memadai. Artikel ini bersifat library research (penelitian kepustakaan) yang terdiri dari kitab-kitab hadis terkait khitbah (primer) dan al-Qur'an

1Zainuddin Ali, Hukum Perdata Islam di Indonesia (Cet. VI; Jakarta: Sinar Grafika, 2012), h. 11. 
serta pendapat para ulama dan pakar terkait topik bahasan (sekunder).

\section{Pembahasan}

\section{A. Ontologi Khitbah (Peminangan)}

Khitbah dan al-khatab berasal dari bahasa Arab dan dari kata yang sama yang berarti "pembicaraan" dan jika terkait ihwal perempuan, maka makna yang pertama kali ditangkap adalah percakapan yang terkait dengan masalah pernikahannya ${ }^{2}$, hematnya, khitbah berarti percakapan yang berkaitan dengan lamaran untuk menikah. Sedangkan kosa kata "peminangan" berasal dari kata "pinang"-“meminang”, yang berarti meminta seorang perempuan (untuk dijadikan istri) ${ }^{3}$ dan bersinonim dengan kata "melamar", serta dalam bahasa Arab disebut "khitbah" (الخطبة), yang maksudnya meminta seorang perempuan untuk dijadikan istri ${ }^{4}$ atau upaya untuk terlibat dalam hubungan perjodohan antara seorang pria dan seorang wanita dengan ccara-cara yang baik (ma'ruf) ${ }^{5}$ dan umumnya berlaku di suatu masyarakat ${ }^{6}$ Peminangan merupakan awal sebelum menikah, sehingga kedua belah pihak saling mengenal hingga pernikahan berdasar pandangan yang jelas. ${ }^{7}$ Pinangan bukan suatu akad (transaksi) tetapi berupa lamaran atau permohonan untuk menikah, jadi ketika menerima

${ }^{2}$ Cahyadi Takariawan, Izinkan Aku Meminangmu (Solo: Era Intermedia, 2004), h. 52.

${ }^{3}$ https://kbbi.kemdikbud.go.id/entri/meminang (diakses pada tanggal 29 September 2018)

${ }^{4}$ Amir Syarifuddin, Garis-Garis Besar Fiqh (Cet. IV; Jakarta: Kencana, 2013), h. 82

5Undang-Undang RI Nomor 1/1974 Tentang Perkawinan \& Kompilasi Hukum Islam (Bandung: Citra Umbara, t. th), h. 227.

${ }^{6}$ Abdul Rahman Ghozali, Fiqh Munakahat (Cet. V; Jakarta: Kencana, 2003), h. 73-74.

${ }^{7}$ Abdul Rahman Ghozali, Fiqh Munakahat, h. 77.

TAHDIS Volume 9 Nomor 2 Tahun 2018 
suatu pinangan tidak berarti ada akad pernikahan antara kedua pihak, dimana pria merupakan calon suami bagi seseorang wanita di masa depan. Adapun pertunangan merupakan proses menunggu akad nikah diantara kedua belah pihak yang diberi ikatan seperti pemberian cincin atau lainnya yang mungkin bisa berbeda dalam suatu daerah. Beberapa makna yang telah ditunjukkan, bahwa esensi dari khitbah adalah untuk menyampaikan niat menikahi seseorang.

Peminangan biasanya dilakukan oleh pria kepada wanita, akan tetapi tidak ada larangan bagi wanita untuk melamar pria ${ }^{8}$, diizinkan pula bagi wali wanita untuk menawarkan pernikahan mereka kepada seorang pria. Seorang wanita dapat mengekspresikan keinginannya sendiri untuk menikahi pria dan meminta untuk menikah tetapi harus tetap berpegang pada nilai/adat yang berlaku di tengah masyarakat Muslim dan keikhlasan menjaga kesucian dan martabat. ${ }^{9}$ Kisah Nabi saw. disebutkan bahwa ketika Khadijah terkesan dengan akhlak yang dimiliki Rasulullah saw. sehingga dia (Khadijah) ingin menjadikan Nabi saw. sebagai suaminya. Khadijah mengirim Ya'la bin Umayyah untuk lebih mengetahui lebih jauh keberadaan Muhammad saw. dan meminta untuk menikahinya, dan Nabi saw. menyetujuinya. Bersama pamannya, Nabi pergi menemui Amru bin As'ad untuk mengajukan pinangan ke Khadijah, dimana saat itu usia Nabi 25 tahun dan Khadijah berusia 40 tahun. ${ }^{10}$ Khitbah memiliki beberapa persyaratan yang dibagi menjadi dua kategori, yaitu:

a) Persyaratan mustahsinah, yaitu persyaratan yang berupa "anjuran" (tidak wajib) seorang pria yang akan meminang

${ }^{8} \mathrm{Abu}$ Al-Ghifari, Pacaran Yang Islami Adakah?(Bandung: Mujahid Press, 2003), h. 494

${ }^{9} \mathrm{Abu}$ Al-Ghifari, Pacaran Yang Islami Adakah?, h. 124.

${ }^{10}$ Hasbi Indra, Iskandar Ahzada dan Husnani, Potret Wanita Shalehah, h. 25.

TAHDIS Volume 9 Nomor 2 Tahun 2018 
perempuan untuk memeriksa perempuan yang akan dipinangnya, apakah sudah sesuai harapannya atau belum, demi menjamin kelangsungan hidup dari sebuah rumah tangga yang harmonis. ${ }^{11}$ Diantara syaratnya yaitu:

$\checkmark$ Perempuan yang akan dipinang sebaiknya "setara" dengan pria yang meminang, baik fisik maupun non-fisik seperti akhlak dan pengetahuan agama. Harapan dengan adanya "keserasian" dari kedua belah pihak, dapat menciptakan keharmonisan suami-istri yang dapat mendukung untuk mencapai tujuan pernikahan ${ }^{12}$, sebagaimana sabda Nabi saw.:

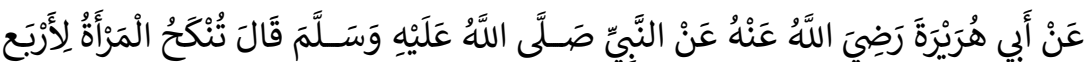

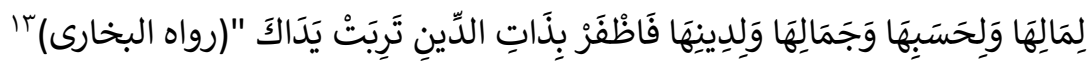

Dari Abu Hurairah ra, dari Nabi saw. beliau bersabda: "Wanita itu dinikahi karena empat hal, karena hartanya, karena keturunannya, karena kecantikannya dan karena agamanya. Maka pilihlah karena agamanya, niscaya kamu akan beruntung. "(HR. al-Bukhari)

$\checkmark$ Perempuan yang akan dipinang mempunyai sifat penyayang dan dapat melahirkan keturunan (sehat jasmani), dan sebaliknya, perempuan yang dipinang sebaiknya mengetahui pula kondisi pria yang meminangnya. ${ }^{14}$

b) Persyaratan lazimah, merupakan syarat yang harus dipenuhi sebelum khitbah dilakukan. ${ }^{15}$ oleh karena itu, sahnya sebuah

${ }^{11}$ Hady Mufa'at Ahmad, Fikih Munakahat (t. tt: Duta grafika, 1992), h. 37.

12Hady Mufa'at Ahmad, Fikih Munakahat (t. tt: Duta grafika, 1992), h. 37-38

${ }_{13}^{13}$ Muhammad Ibn Ismā'il Abū 'Abdullah al-Bukhārì, Șahịh al-Bukhāri, (Cet. II;

Bairūt: Dār Ibnu Kas̄îr, 1987/1407), h. 1958.

${ }^{14}$ Kamal Mukhtar, Asas-asas Hukum Islam Tentang Perkawinan (Jakarta: Bulan Bintang, 1993), h. 35.

15Kamal Mukhtar, Asas-asas Hukum Islam Tentang Perkawinan, h. 33

TAHDIS Volume 9 Nomor 2 Tahun 2018 
pinangan tergantung kepada persyaratan lazimah, diantaranya:

1) Perempuan yang akan dipinang bukan dalam pinangan pria lainnya sampai pria tersebut melepas pinangannya. ${ }^{16} \mathrm{Nabi}$ saw. bersabda:

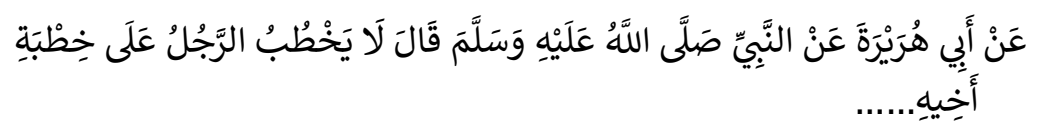

Dari Abu Hurairah dari Nabi saw. beliau bersabda: "Janganlah meminang wanita yang telah dipinang saudaranya...

2) Perempuan yang akan dipinang bukan pada masa iddah, dan jika pada iddah raj'i maka yang berhak mengawininya adalah mantan suaminya, disamping itu ada empat hal yang terkait, diantaranya:

a. Kebolehan meminang seorang wanita cerai yang belum disetubuhi, disebabkan tidak masuk pada masa iddah dalam kesepakatan para ulama, sesuai QS. Al-Ahzab/33: 49.

b. Tidak bolehnya melamar wanita yang telah ditalak raj'i, baik terang-terangan ataupun tidak, hal ini disebabkan karena masih sebagai wanita yang diperistri.

c. Kebolehan meminang seorang wanita dengan isyarat (tertutup) dan tidak terbuka atau terang-terangan bagi wanita dalam masa iddah disebabkan wafatnya suami. ${ }^{17}$

${ }^{16}$ A. Rofiq, Hukum Islam di Indonesia (Jakarta: Raja Grafindo Persada, 1998), h. 65

${ }^{17}$ Busainan al-Sayyid al-Iraqy, Rahasia Pernikahan yang Bahagia (Jakarta: Pustaka Azzam, 2002), h. 54-55. 
d. Ketidakbolehan meminang seorang wanita yang sedang dalam ikatan pernikahan dengan pria lainnya. ${ }^{18}$ Baik secara tersirat maupun tersurat.

B. Esensi Peminangan dalam Hadis Nabi saw.

Peminangan atau khitbah, yakni menampakkan keinginan menikah terhadap seorang perempuan tertentu dengan memberitahu perempuan yang dimaksud atau keluarganya (walinya) ${ }^{19}$, yang pelaksanaannya diadakan sebelum terjadinya akad nikah, dan hal ini sudah membudaya di masyarakat Indonesia, adapun prosesnya tergantung budaya masingmasing daerah. Perbedaan "khitbah" dan "zawwaj" (menikah) ialah dimana zawwaj merupakan akad yang nantinya akan mengikat berbagai hal, berada dalam batas, syarat, hak tertentu. Hal ini berbeda dengan khitbah, yang hanya mengumumkan kemauan untuk menikahi calon istri. Hal ini terlihat dari perbedaan definisi dua kata tersebut di dalam berbagai kamus. Peminangan masyarakat sekarang sudah membudaya yang disertai ritual tertentu seperti selamatan, tukar cincin dan lain sebagainya. ${ }^{20}$ Pinangan pria kepada wanita belum pasti menjadi mahramnya sampai akad nikah dilakukan, oleh karena itu tidak menjamin berlangsung ke jenjang pernikahan, sehingga kedua belah pihak sebaiknya menjaga batasan pergaulan.

Masa setelah khitbah dilakukan ialah masa dimana calon suami sudah berkomitmen untuk menikah, oleh karena itu upaya mengenal dengan baik calon istri hendaknya dilakukan sebelum khitbah, dimana keyakinan memilih sudah dimiliki, disamping itu keluarga sudah menyetujui calon istri yang

${ }^{18}$ Muhammad Ali al-Ṣabuni, Pernikahan Dini (Kairo: Pustaka al-Naba, 2002), h. 57

19Khurnia, Memadukan Dakwa dan Keharmonisan Rumah Tangga (Bogor: alAzhar Press, 2005),h. 278.

${ }^{20}$ Genta Tiar, Ta'aruf Khitbah Nikah + Malam Pertama (Cet I; Surabaya: Genta Hidaya, 2017), h. 240.

TAHDIS Volume 9 Nomor 2 Tahun 2018 
diajukan, harapannya agar peluang batalnya pernikahan kecil, meski takdir Allah menghendaki hal lainnya. 21 Khalid Abddurrahman berpendapat, langkah awal pernikahan yakni dengan meminta "persetujuan" izin dari calon istri, jika memberikan izin (dan mengarahkan) kepada wali, maka niat pernikahan tersebut boleh untuk dilaksanakan, dan jika dipaksa calon istri menerima diluar "persetujuan"-nya akan beresiko berakhir perceraian, sehingga Islam melarang adanya unsur pemaksaan dalam pernikahan ${ }^{22}$ Nabi saw. bersabda:

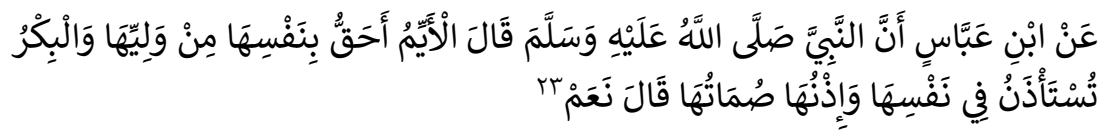

Dari Ibnu Abbas bahwa Nabi saw. telah bersabda: "Seorang janda lebih berhak atas dirinya dari pada walinya, sedangkan anak gadis harus di mintai izin darinya, dan izinnya adalah diamnya"? Dia menjawab; "Ya. "(HR Muslim)

Riwayat hadis Ahmad, Ibnu Majah dan al-Nasa'i dari Ibnu Buraidah bahwasanya telah ada seorang wanita (gadis) datang ke Nabi saw. dan berkata: ya Rasulullah, ayahku telah menikahkan aku dengan sepupuku agar menaikkan kedudukannya, padahal aku tidak menyenanginya'. Maka Rasulullah saw. memberinya pilihan antara menerima atau menolaknya, kata gadis tersebut: 'aku terpaksa menerima perlakuan ayahku, tetapi aku ingin memberitahu kepada seluruh wanita bahwa wali tidak berhak memaksa gadisnya menikah

${ }^{21}$ Abu Sahla dan Nurul Nazara, Buku Pintar Pernikahan (Cet. I; Jakarta: Belanoor, 2011), h. 41

${ }^{22}$ Khalid Abdurrahman al-'ikk, Kado Pintar Nikah: Merajut dan Membina Rumah Tangga dari Pra Hingga Pasca Pernikahan (Cet. I; Semarang: Pustaka Adnan, 2012), h. 47 - 49.

${ }^{23}$ Muslim bin al-Ḥajjāj bin al-Muslim al-Qusyairī al-Naisabūrỉ, Șaḥị̣ Muslim, Juz. II (Bairūt: Dār al-Āfaq, t. th), h. 1037 
dengan laki-laki yang tidak disenanginya'.24 Dikisahkan dalam sebuah hadis, bahwa Fatimah binti Qays menerima dan menolak pinangan.

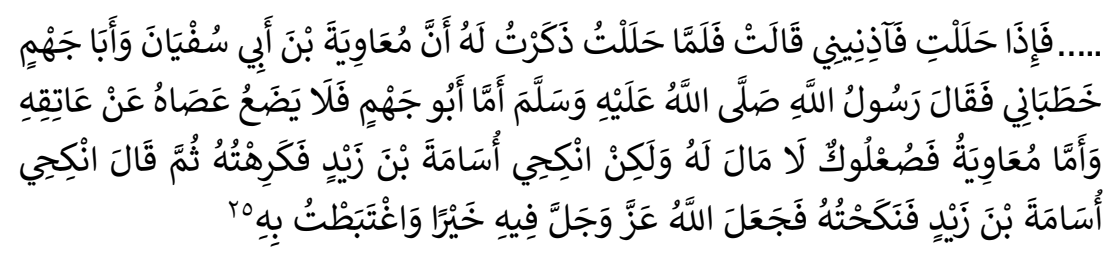

Kemudian apabila engkau telah halal maka beritahu saya." Ia berkata; kemudian setelah halal, saya menyebutkan kepada beliau bahwa Mu'awiyah bin Sufyan dan Abu Jahm telah melamarnya. Kemudian Rasulullah saw. bersabda: "Adapun Abu Jahm maka ia tidak pernah meletakkan tongkatnya dari pundak, adapun Mu'awiyah maka ia adalah orang yang miskin tidak memiliki harta. Akan tetapi menikahlah dengan Usamah bin Zaid." Lalu saya membencinya, kemudian beliau bersabda: "Menikahlah dengan Usamah bin Zaid." Maka saya menikah dengannya. Lalu Allah 'azza wajalla menjadikan padanya kebaikan dan sayapun iri kepadanya (HR Sunan al-Nasäī)

Setelah Fatimah binti Qays melalui masa iddahnya, Fatimah dikhitbah oleh dua pria, yaitu Abū Jahm dan Mu'āwiyah bin Abū Sufyān dan belum menerima pinangan keduanya. Bermaksud meminta nasihat ke Rasul, dan Nabi saw. menginfokan "kondisi" dari keduanya, dimana Abū Jahm merupakan laki-laki yang tidak pernah meletakkan tongkat yang dibawanya di pundak dengan kata lain Abu Jahm merupakan laki-laki yang memiliki karakter keras, suka merantau, dan

${ }^{24}$ Khalid Abdurrahman al-'ikk, Kado Pintar Nikah: Merajut dan Membina Rumah Tangga dari Pra Hingga Pasca Pernikahan, h. 49.

${ }^{25}$ Aḥmad bin Syu'aib Abū 'Abd al-Raḥmān al-Nasā'i, Sunan al-Nasảî̉, Juz. 6 (Cet.VII; t.t.:Maktabah al-Mațbu'ah al-Islāmīyah, 1406/1986), h. 75.

TAHDIS Volume 9 Nomor 2 Tahun 2018 
sering bepergian sehingga kelak istrinya sering ditinggal untuk bepergian, sedangkan Mu'awiyah merupakan orang yang tidak berharta atau orang miskin sehingga kehidupannya kurang makmur. Lamaran laki-laki seperti inilah yang boleh ditolak menurut Rasulullah ${ }^{26}$. Nabi saw. tidak mengatakan kemiskinan menjadi sebab ditolaknya lamaran, akan tetapi dalam konteks ini, Rasulullah memilih Usamah bin Zaid sebagai suami Fatimah karena adanya "kelebihan dan kecocokan", dengan harapan Fatimah dapat hidup dengan bahagia dengannya. Selain itu Usamah bin Zaid memiliki keimanan dan ketakwaan yang kuat kepada Allah swt. Sehingga dapat menjadi imam yang baik untuk istri dan anak-anaknya kelak. Setelah menikah dengan Usamah bin Zaid, Fatimah merasa sangat beruntung dan bahagia, sebagaimana dijelaskan pada hadis di atas. Selagi wanita belum memastikan menerima lamaran seseorang pria, maka boleh melamar wanita yang sudah dilamar pria lain sebelumnya. Umar bin Khattab pernah melamarkan seorang perempuan untuk tiga orang pria yang berbeda (Marwan bin al-Hakam, Abdullah bin Umar dan Jarir bin Abdullah), hal ini menujukkan kebolehan meminang wanita yang sudah dilamar orang lain dimana wanita tersebut belum memberikan dan memastikan pilihan sebelumnya, hal ini dikuatkan oleh Imam Syafi'i akan bolehnya melamar wanita yang belum memberikan pilihan pasti calon suami. 27

C. Ketentuan Peminangan

Secara syariat, wanita yang boleh dikhitbah memiliki beberapa persyaratan, diantaranya:

${ }^{26}$ Mila Zahir, “Mengapa Fatimah Menolak Lamaran 2 Laki-Laki Ini?”, RuMu, Inspiring and educating Muslim Woman, https://www.ruangmuslimah.co/13929mengapa-fatimah-menolak-lamaran-2-laki-laki-ini (1 Oktober 2018)

${ }^{27}$ al-Syarbini, Mughni al Muhtaj, Juz. 4(Cet. I; Bairūt: Där al-Kutub al-Ilmiyah, 1994), h. 222. 
1. Bukan wanita yang haram dinikahi, terbagi dalam dua kategori, yaitu:

a. Wanita yang diharamkan untuk selamanya, ini terbagi menjadi tiga ${ }^{28}$ yaitu adanya hubungan nasab ${ }^{29}$ (keturunan), sesusuan $^{30}$ dan mușoharoh ${ }^{31}$

b. Wanita yang diharamkan dalam batasan waktu, diantaranya: dua bersaudara haram dinikahi oleh seorang laki-laki dalam waktu yang bersamaan, maksudnya mereka haram dimadu dalam waktu yang sama (al-Nisā/4: 23); wanita yang masih dalam iddah; wanita yang ditalak tiga hingga dia menikah dengan pria lain; wanita yang sedang ihrom; haram bagi pria kafir sampai menjadi muslim; wanita kafir hingga memeluk Islam; istri pria lain; wanita pezina/pelacur diharamkan hingga dia bertaubat serta selesai dari masa iddahnya. ${ }^{32}$

2. Bukan wanita yang menjalani masa 'iddah. ${ }^{33}$

a. Masa iddah yang disebabkan meninggalnya suami.

b. Masa iddah yang disebabkan talak ba'in, para ulama sepakat bahwa tidak bolehnya meminang wanita pada masa iddah talak ba'in qubra (talak 3 kali), talak ba'in qubra ini membuat pasangan suami istri memutuskan hubungan, tidak ada harapan untuk kembali sebelum dinikahi oleh pria lain, hal

${ }^{28}$ Soemiyati, Hukum perkawinan Islam dan UU perkawinan (Liberty : Yogyakarta, 2007), h. 33.

29 Terdiri dari ibu kandung, nenek (pihak ayah dan ibu), anak perempuan, saudara perempuan (seayah seibu, atau seibu, seayah), saudara-saudara perempuan ayah (kandung, seayah seibu, seayah, seibu, seterusnya keatas), saudara-saudara ibu yang perempuan, anak perempuan saudara, anak perempuan istri (anak tiri) (alNisā/4: 23).

${ }^{30}$ lima kali susuan atau lebih ketika masih bayi dibawah umur dua tahun.

31 ibu-ibu istrimu (mertua); anak-anak tiri, menantu, ibu tiri.

${ }^{32}$ Muhammad Saleh Al-Usmani, Pernikahan Islami: Dasar Hukum Hidup Berumah Tangga (Risalah Gusti, 1991), h. 11

${ }^{33}$ Abdur Rahman Ghozali, Fiqh Munakahat (Jakarta: Kencana, 2003), h. 80. 
ini berbeda dengan talak ba'in sugrah, dimana wanita yang ditalak (2 kali) masih halal bagi suami untuk rujuk dengan akad nikah dan mahar yang baru.

c. Masa iddah yang disebabkan talak raj'i (suami boleh kembali ke istri karena talaknya belum 3 kali) dimana istri yang ditalak masih berstatus istri, suami boleh kembali ruju' tanpa adanya akad serta mahar.

d. Masa iddah yang disebabkan khulu atau fasakh, wanita yang iddah disebabkan khulu34, atau karena fasakh ${ }^{35}$ disebabkan suami tidak memberikan nafkah atau menghilang/tidak pernah pulang.

3. Bukan perempuan yang (menyetujui) sudah dikhitbah oleh pria lain.

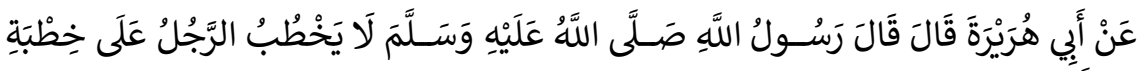
أَخِيه

Dari Abī Hurairah, ia berkata; Rasulullah saw. bersabda: "Tidak boleh seorang laki-laki meminang pinangan saudaranya." 36

Al-Khațāāi berpendapat bahwa adanya larangan tersebut bukan bertujuan pengharaman, meski mayoritas ulama menilainya dalam bentuk pengharaman ${ }^{37}$, melainkan sebagai alta'dib (mendidik, adab serta sopan santun) ${ }^{38}$, dan pada sisi yang lain juga memahaminya dalam perspektif tasawuf, diajarkan

34 talak karena permohonan istri dengan hadiah.

35 adasesuatu yang merusak keabsahan nikah.

${ }^{36}$ Sulaimān Ibn al-Asy'aṡ Abū Dāwud al-Sajastanī al-Azadi, Sunan Abī Dāwud, Juz. 2 (t.t.: Dār al-Fikr, t.th) h. 228.

${ }^{37}$ Muhammad bin Ismāîil al-Amīr al-Kaḥlānỉ al-Ṣan'ānī, Subul al-Salām, Juz 3 (Cet. IV; Maktabah al-Muștafā al-Bābī al-Halbi, 1960), h. 113.

${ }^{38}$ Muhammad bin Ismāíil al-Amìr al-Kaḥlānỉ al-Ṣan'ānī, Subul al-Salām, Juz 3 (Cet. IV; Maktabah al-Muștafā al-Bābỉ al-Ḥalbi, 1960), h. 113.

TAHDIS Volume 9 Nomor 2 Tahun 2018 
untuk tidak (larangan) menyakiti orang lain. ${ }^{39}$ Akan tetapi, AlJazari dalam kitab al-Nihāyah, dikutip oleh al-Mubārafūrì, bahwasanya larangan mengkhitbah wanita yang dikhitbah terjadi di mana sebelumnya kedua pihak telah sepakat terkait mahar, saling ridha dan tersisa hanya proses akad nikah saja. ${ }^{40}$ Khitbah adalah hak setiap orang, selama tidak ada ketentuan yang membatasi hal itu, dalam kasus peminangan, yang pada awalnya merupakan hak setiap orang, itu menjadi hak istimewa ketika ia dipinang oleh orang lain, tetapi juga, dalam masa khiyar, pinangan bukanlah suatu kepastian untuk dilanjutkan ke jenjang selanjutnya.

Hadis terkait melamar pinangan pria lain di atas, pada waktu itu Nabi saw. ditanya tentang seorang yang meminang wanita dan diterima untuk dilanjutkan ke jenjang pernikahan, namun ada pria lain yang ternyata lebih menarik baginya daripada pria pertama sehingga dia membatalkan pinangan pertamanya. Adapun dalam cerita Fatimah konteksnya berbeda, dimana Fatimah binti Qais datang kepada Nabi Muhammad saw. sambil mengatakan bahwa dia dipinang Mu'awiyah serta $\mathrm{Abu}$ Jahm. Nabi saw. tahu bahwa Fatimah sendiri tidak suka dan belum menerima kedua khitbah tersebut, oleh karena itu Fatimah mendatangi Nabi untuk mempertimbangkan serta meminta nasihat, kemudian Nabi memberi solusi dengan mengusulkan Usamah. Ini menggambarkan bahwa hadis pertama berbeda dari hadis kedua, dimana hadis pertama dari kondisi dimana seorang wanita dengan persetujuan wali telah menerima pinangan, sehingga dia tidak dapat menerima pinangan pria lain, sementara pada hadis kedua, dalam kondisi

${ }^{39}$ Ali Ibn Ahmad Ibn Hajar al-'Asqalani, Fath al-Barī Syarh Șahih al-Bukhāri, Juz 14 (t.tp.: Dār al-Kutub al- Salafiyah, 2015), 405

${ }^{40}$ Muhạmmad 'Abd al-Raḥmān bin 'Abd al-Raḥimm al-Mubārakfūrī, Tuhffah alAhważī bi Syarh Jāmi' al-Tirmizìi, Juz 4 (Bairūt: Dār al-Kutub al-'Ilmiyyah), h. 239. 
dimana seorang pria sebatas pengajuan pinangan, tidak ada kepastian bahwa dia diterima atau ditolak, maka kondisi seperti itu seorang wanita dapat menolak pinangan. Singkatnya, larangan meminang pinangan orang lain dapat dibolehkan apabila ada tiga aspek berikut; pertama, wanita atau walinya menolak pinangan pria pertama; kedua, pria tersebut memang tidak/belum mengetahui bahwa wanita tersebut telah dipinang pria lain; ketiga, peminang yang pertama membolehkan/mengizinkan peminang kedua untuk meminang wanita tersebut dengan berbagai pertimbangan.

D. Kebijaksanaan serta Hikmah dalam Peminangan

Ulama membolehkan memandang perempuan yang ingin dinikahinya sebagaimana dalam QS. al-Ahzāb/33: 52, hal ini disebabkan bertemunya mata ke mata menjadi bertemunya hati dan berlarutnya jiwa ${ }^{41}$, melihat hal yang dapat membuat pria tertarik atau tidak tertarik sebelum melanjutkan ke jenjang berikutnya. Nabi saw. pun menganjurkan untuk melakukannya:

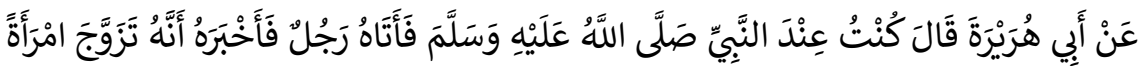

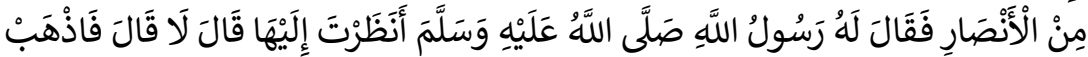

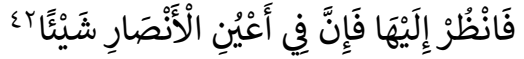

Dari Abu Hurairah berkata; "Saya pernah berada di samping Nabi saw. tiba-tiba seorang laki-laki datang kepada beliau seraya mengabarkan bahwa dirinya akan menikahi seorang wanita dari Anshar." Lantas Rasulullah saw. bersabda kepadanya: "Apakah kamu telah melihatnya? Dia menjawab;

${ }^{41}$ Mu'ammal Hamidy, Halal dan Haram dalam Islam (t. tt: PT. Bina Ilmu, 1j993), h. 35

${ }^{42}$ Muslim bin al-Ḥajjāj bin al-Muslim al-Qusyairī al-Naisabūrì, Ṣaḥih Muslim, Juz. II, h. 1040 
Tidak. Beliau melanjutkan: "Pergi dan lihatlah kepadanya, sesungguhnya di mata orang-orang Anshar ada sesuatu."

Hikmah dibolehkannya "melihat" wanita yang ingin dipinang dan dinikahi yakni supaya jiwa terasa tenang untuk melanjutkan kejenjang berikutnya, hal ini berbeda jika seorang pria belum melihat calonnya dan mendapati sesuatu yang tidak sesuai dengan harapannya. Oleh sebab itu Nabi saw. memberikan anjuran kepada pria yang ingin meminang untuk melihat dahulu calon istrinya, supaya tidak ada penyesalan kemudian, Rasulullah saw. bersabda:

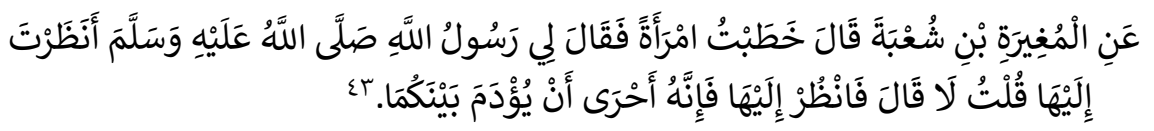

Dari al-Mughirah bin Syu'bah ia berkata, "saya meminang seorang wanita, Rasulullah saw. lalu bertanya kepadaku: "Apakah kamu telah melihatnya?" saya menjawab: "belum." beliau bersabda: "lihatlah ia karena itu akan lebih memantapkan kalian berdua."(HR Ahmad bin Ḥanbal)

Hadis di atas pada kata ahrā bermakna ajdar, aulä: lebih utama, lebih pantas dan lebih sesuai. Sedangkan kalimat ayyu'dama bainakuma- bermakna menyatukan, menghimpun dan mencocokkan. ${ }^{44}$ Proses melihat calon istri (naz̧ar) dilakukan sebelum peminangan bersifat dianjurkan (mandub), dan jika tidak menyukainya, hendaklah menolak dengan cara yang santun. Diperbolehkan jika si calon suami ingin memakai

${ }^{43} \mathrm{Abu}$ 'Abdullāh Aḥmad bin Muḥammad bin Ḥanbal bin Hilāl bin Asad alSyaibānī, Musnad Ahmad bin Hanbal, Juz 4, h. 244.

${ }^{44}$ Muhammad 'Abd al-Raḥmān bin 'Abd al-Raḥimm al-Mubārakfūrī, Tuhfah alAhważī bi Syarh Jämi' al-Tirmiżī, h. 175.

TAHDIS Volume 9 Nomor 2 Tahun 2018 
perantara seseorang untuk menjelaskan keadaan calon pasangannya. ${ }^{45} \mathrm{Nabi}$ saw. bersabda:

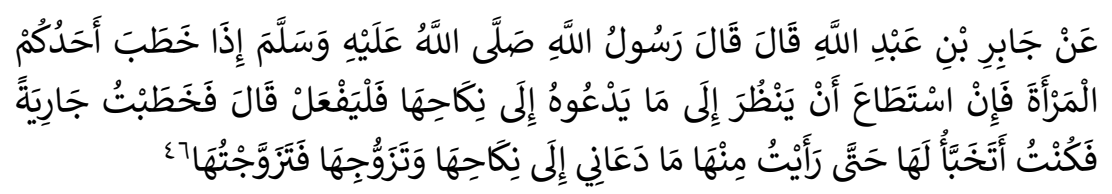

Dari Jabir bin Abdullah, ia berkata; Rasulullah saw. bersabda: "apabila salah seorang di antara kalian meminang seorang wanita, jika ia mampu untuk melihat sesuatu yang mendorongannya untuk menikahinya hendaknya ia melakukannya." Jabir berkata; kemudian aku meminang seorang gadis dan aku bersembunyi untuk melihatnya hingga aku melihat darinya apa yang mendorongku untuk menikahinya, lalu aku pun menikahinya.(HR Abū Dāud)

Secara eksplisit dalam hadis di atas Nabi saw. tidak menentukan batas ukuran yang boleh dilihat, akan tetapi jumhur 'ulama berpendapat bahwa yang boleh dilihat yakni wajah beserta kedua telapak tangan yang menjadi representasi untuk melihat kecantikan dan tingkat kesuburan. ${ }^{47}$ Ibnu 'Adin berpendapat, dibolehkan melihat wajah, kedua telapak tangan serta kedua kaki dan tidak lebih dari pada itu. Ada juga dari kalangan ulama yang berpendapat bahwa seorang laki-laki boleh melihat perempuan yang hendak dipinang dengan berpakaian yang boleh dilihat oleh ayah dan mahramnya yang lain, akan tetapi pria tersebut boleh pergi dengan disertai oleh ayah atau salah seorang dari mahramnya untuk mengetahui

45Muhammad bin Ismā'il al-Amīr al-Kaḥlānī al-Ṣan'ānī, Subul al-Salām, juz 3 (Cet. IV; Maktabah al-Mușțafā al-Bābī al-Ḥalbi, 1960), h. 113.

46Sulaimān Ibn al-Asy'as̉ Abū Dāwud al-Sajastanī al-Azadi, Sunan Abī Dāwud, Juz. II, h. 228.

${ }^{47}$ Muhammad bin Ismā'il al-Amīr al-Kahlānī al-Ṣan'ānì, Subul al-Salām, h. 113. 
kecerdikan, perasaan dan kepribadian calon istri. ${ }^{48}$ Sabda Nabi saw.:

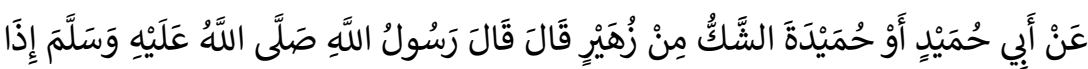

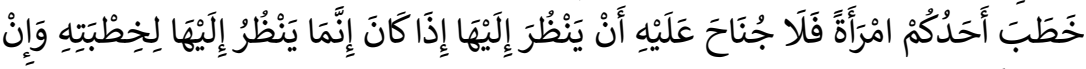

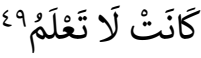

Dari Abu Humaid atau Humaidah, keraguan ada pada Zuhair, dia berkata; Rasulullah saw. bersabda: "jika seseorang dari kalian melamar seorang wanita, maka tidak mengapa baginya untuk melihat wanita tersebut, hanya saja dia melihatnya hanya untuk melamarnya saja meskipun wanita tersebut tidak mengetahuinya.

Dalam proses nazar (melihat calon istri) terdapat beberapa syarat yang harus dipenuhi, pertama calon suami telah memiliki niat kuat untuk menikah sebagaimana hadis Nabi di atas: "jika memang dia melihatnya hanya untuk pelamarannya". Kedua, batasan bolehnya memandang sangat terpaut dengan etika dan budaya yang esensinya ialah dapat "melihat" ketertarikan diri untuk menikahinya. Hal ini (nazar) berupa rukhșah (keringanan) dimana syari'at membolehkan hanya bagi orang yang berniat melamar, selain itu maka hukum nya haram sesuai dalam QS al-Nūr/24: 31. Selain itu, bukan hanya pria yang dapat "melihat" calon istri akan tetapi juga tertuju kepada wanita melihat calon suami yang hendak melamarnya. ${ }^{50}$

${ }^{48}$ Quraisyh Shihab, Pengantin Al-Qur'an Kalung Permata Buat Anak-Anakku (Cet. VIII; Jakarta: Lentera Hati, 2011), h. 79.

${ }^{49} \mathrm{Aḥmad}$ ibn Ḥanbal Abū 'Abdullah al-Syaibānī, Musnad al-Imām Ahmad Ibnu Hanbal, Juz. 39, h. 15

${ }^{50}$ Dwi Andi Lubis, Menjadi Pengantin Sepanjang Masa (Cet. I; Solo: Aqwam, 2008), h. 98-100

TAHDIS Volume 9 Nomor 2 Tahun 2018 


\section{Penutup}

Peminangan merupakan upaya membangun pernikahan yang harapannya kelak menjadi keluarga yang sakinah mawaddah wa rahmah, dimana seorang pria meminta seorang wanita untuk dijadikan istri/ pasangan hidup, dengan cara yang diberkati dengan pernikahan dalam kemudahan proses pelamaran, menegaskan dan tidak membebani. Peminangan dalam Islam (khitbah) dapat menguatkan hati kedua calon pasangan suami-istri, oleh sebab itu untuk menguatkan dan memantapkan hati keduanya, dibolehkan untuk melihat atau memandang terlebih dahulu (sebelum dikhitbah), agar tidak penyesalan yang muncul setelah akad dilaksanakan, dengan pemahaman ini diharapkan masyarakat lebih mendalam pemahamannya terkait konsep khitbah dalam Islam, khususnya yang tertera dalam kitab hadis nabi saw.

\section{Daftar Pustaka}

al-Qur'an al-Karim

al-'Asqalānī, Ibnu Hajar Abū al-Faḍl Aḥmad bin 'Ali bin Hajar. Fath al-Bari Syarh Șahih al-Bukhäri. t.tp.: Dār al-Kutub alSalafiyah, 2015.

al-'Ikk, Khalid Abdurrahman. Kado Pintar Nikah: Merajut dan

Membina Rumah Tangga dari Pra Hingga Pasca

Pernikahan. Cet. I; Semarang: Pustaka Adnan, 2012.

Ahmad, Hady Mufa'at. Fikih Munakahat. t.t.: Duta grafika, 1992. Ali, Zainuddin. Hukum Perdata Islam. Cet. IV. Jakarta: Sinar Grafika, 2012.

Azadi, Sulaimān Ibn al-Asy'aś Abū Dāwud al-Sajastanì. Sunan Abī Dāwud. t.t.: Dār al-Fikr, t.th.

al-Bukhārī, Muḥammad Ibn Ismā'il Abū 'Abdullah. Șaḥị̣ alBukhāri. Cet. II; Bairūt: Dār Ibnu Kas̄īr, 1987/1407. 
GhazaIi, Abdul Rahman. Fiqh Munakahat. Cet. I; Bogor: Kencana, 2003.

al-Ghifari, Abu. Pacaran Yang Islami Adakah?. Bandung: Mujahid Press, 2003.

Hamidy, Mu'ammal. Halal dan Haram dalam Islam. t.t.: PT. Bina Ilmu, 1993.

Husnani, Hasbi Indra, Iskandar Ahzada. Potret Wanita Shalehah.

Cet. III; Jakarta: Penamadani, 2004.

al-Iraqy, Busainan al-Sayyid. Rahasia Pernikahan yang Bahagia.

Jakarta: Pustaka Azzam, 2002.

Khurnia. Memadukan Dakwa dan Keharmonisan Rumah Tangga.

Bogor: al-Azhar Press, 2005.

Lubis, Dwi Andi. Menjadi Pengantin Sepanjang Masa. Cet. I; Solo: Aqwam, 2008.

al-Mubārakfūrī, Muḥammad 'Abd al-Raḥmān bin 'Abd al-Raḥim.

Tuhffah al-Aḥwazī bi Syarh Jāmi' al-Tirmizì. Bairūt: Dār alKutub al-'Ilmiyyah, t.th.

Mukhtar, Kamal. Asas-asas Hukum Islam Tentang Perkawinan. Jakarta: Bulan Bintang, 1993.

al-Naisabūrī, Muslim bin al-Hajjāj bin al-Muslim al-Qusyairī. Șahịh Muslim. Bairūt: Dār al-Āfaq, t.th.

al-Nasā'i, Aḥmad bin Syu'aib Abū 'Abd al-Raḥmān. Sunan alNasa'î. Cet.VII. t.t.:Maktabah al-Mațbu'ah al-Islāmīyah, 1406/1986.

Nazara, Abu Sahla dan Nurul. Buku Pintar Pernikahan. Cet. I; Jakarta: Belanoor, 2011.

Rofiq, A. Hukum Islam di Indonesia. Jakarta: Raja Grafindo Persada, 1998.

al-Șabuni, Muhammad Ali. Pernikahan Dini. Kairo: Pustaka alNaba, 2002. 
al-Ṣan'ānī, Muḥammad bin Ismā'il al-Amīr al-Kaḥlānī. Subul alSalām. Cet. IV. Maktabah al-Muștafā al-Bābỉ al-Ḥalbi, 1960.

Shihab, M. Quraish. Pengantin Al-Qur'an : Kalung Permata Buat Anak-Anakku. Cet. VIII; Jakarta: Lentera Hati, 2011. al-Syaibānī, Ahmad ibn Hanbal Abū 'Abdullah. Musnad al-Imām Ahmad Ibnu Hanbal. Kairo: Mu'assasa al-Qurțuba, t.th. al-Syarbini. Mughni al Muhtaj. Cet. I. Bairūt: Där al-Kutub alIlmiyah, 1994.

Syarifuddin, Amir. Garis-Garis Besar Fiqh. Cet. IV. Jakarta: Kencana, 2013.

Takariawan, Cahyadi. Izinkan Aku Meminangmu. Solo: Era Intermedia, 2004.

Tiar, Genta. Ta'aruf Khitbah Nikah + Malam Pertama. Cet I; Surabaya: Genta Hidaya, 2017.

al-Usmani, Muhammad Saleh. Pernikahan Islami: Dasar Hukum Hidup Berumah Tangga Risalah Gusti, 1991. 